\title{
The major parties: National's and Labour's employment relations policies
}

\author{
DANAË ANDERSON*, ERLING RASMUSSEN ${ }^{* *}$ and BARRY FOSTER ${ }^{* * *}$
}

\begin{abstract}
The 2020 election campaign has been divisive and extended, with the election date delayed in August by a month (from $19^{\text {th }}$ September) to $17^{\text {th }}$ October. The Covid-19 pandemic has influenced public policies to an unprecedented degree as well as playing havoc with the political parties' voter support. While there, initially, did not seem to be many major policy differences between the two main parties, a clear choice has been established during the election campaign. Aside from National's crucial choice of promising tax cuts and stronger debt reduction targets, a clear distinction in employment relations policies has also been established. Labour continues its policy priorities, which include new employment relations initiatives and large employment support policies, while National pledges more employer-determined flexibility and employee choice in respect of statutory minima and educational opportunities. However, although there have already been many election promises, there appears to be no comprehensive plan from either party of how to establish a sustainable, high skill and highly productive economy along with associated workplace relationships.
\end{abstract}

Keywords: New Zealand general election, major parties' election promises, employment relations, Covid-19 pandemic.

\section{Introduction}

Major and tragic events have been the backdrop of the current Coalition Government's policy making in the last three years. The first included the Christchurch terrorist attacks in February 2019, followed by the White Island volcanic eruption in December 2019. The Covid-19 virus, which began to be reported in China in January 2020, quickly spread internationally, with New Zealand implementing unprecedented lockdown measures and border closure by mid-March. Economic, social and employment relations upheavals, since early 2020, have been dramatic and have shifted the goal posts on many public policy positions.

At mid-September, the polls predicted a very good election result for Labour and an equally bad one for National. In hindsight, it is interesting to contemplate the enormous impact of Covid-19 on election fortunes plus the very negative fallouts from National's internal power struggles. In early 2020, the National opposition was dominating the polls (see Colmar Brunton, 2020; O'Brien, 2020) with a very real possibility that the Coalition Government would be the first oneterm government since 1975 . With criticism of non-delivery on significant policy platforms, such as Kiwibuild, child poverty, and infrastructure, Labour looked vulnerable, despite the popularity of its leader, Prime Minister Jacinda Ardern. Then came the Covid-19 pandemic and everything changed.

\footnotetext{
* Lecturer, Department of Management, Auckand University of Technology, New Zealand

** Professor, Department of Management, Auckland University of Technology, New Zealand

${ }^{\text {*** }}$ Lecturer, School of Management, Massey University, New Zealand
} 
The National Party has since been in turmoil with internal power struggles, leadership changes, and a raft of sitting MPs retiring. This unrest was prompted by a sharp loss in voter support and questions about the style and popularity of National' leader, Simon Bridges. With Todd Muller's successful leadership coup came a change in National's key leaders, and new approaches and policy directions were promised. However, after just 53 days, Todd Muller abruptly resigned, and the new National Party leader was Judith Collins, and with it came another leadership team reshuffle and more highprofile MPs retiring. Initially, it appeared that there would be limited adjustments to policy positions with National running on its ability to manage and expand economic opportunities. However, National has started to shift its policy positions considerablyduring the election campaign: reversing its position on tax cuts, offering stronger support to businesses, an emphasis on employer and employee choice, and a reversal of the Coalition Government's employment relations policies.

It has previously been argued that, under the Employment Relations Act (ERA), there appears to be less of an ideological gap between the two major parties' employment relations positions. This was partly caused by the National Party's decision, in 2007, not to repeal the ERA but instead focussing on specific amendments (see Rasmussen \& Anderson, 2010), and partly due to pressure on the National-led governments to expand legislation in health and safety, to have a stronger focus on employment standards, constraining 'zero-hours' practices, as well as implementing tripartite agreed changes to pay equity in aged care (Foster \& Rasmussen, 2017).

However, during the election campaign, clear differences between the main parties' economic and employment relation policy intentions have become pronounced. The differences are detailed in the rest of the article but appear to coalesce around three areas. First, while both Labour and National have moved away - by a considerable margin - from the previous constraints on public spending and debt, there are now major differences in how the parties will deal with the long-term implications in terms of debt reduction and economic growth policies. Second, there are fundamental employment relations differences in respect to statutory minima, collective bargaining, regulatory enforcement, and welfare support. These differences include National's election promises of returning to the previous position on probationary periods (the so-called '90-day rule'), reversal of recent employment relations policy changes, and opposition to bargaining changes suggested by Labour, such as Fair Pay Agreements, the introduction of minima for contractors, and large scale investments and structural changes in vocational education and training. Third, National's focus on increased employer-driven flexibility and 'opening up' for short- and long-term net migration also provides a distinct difference in approach. Moreover, with National's tax cuts and faster debt reduction targets, there appears to be emerging differences in respect of public sector, welfare, and education expenditures.

\section{Employment relations context and history, 2017-2020}

It is obvious that the 2017 election campaign was conducted in very different circumstances to the current general election, with the dominant themes in 2017 being skill shortages, high net migration figures, and insufficient wage rises and employment standards (Foster \& Rasmussen, 2017; Skilling \& Molineaux, 2017). While the National Party campaigned on its record as a three-term government, the Labour Party advocated more state intervention to influence low pay rates, youth unemployment, and increased collective bargaining support. Following a dramatic campaign where both National and Labour had new leaders, the general election did not provide a clear majority, with NZ First again being in the role of 'kingmaker'. The October announcement of a new NZ First and Labour Coalition Government with support from the Green Party was associated with a detailed Coalition Agreement. Interestingly, there were few employment relations changes announced, besides reducing net migration figures and moving towards a \$20 statutory minimum wage (New Zealand Labour Party and 
New Zealand First, 2017). As a result, there were considerable differences between the Coalition Agreement and Labour's election promises (Foster \& Rasmussen, 2017).

Throughout this election period, National has constantly reminded the Coalition Government about unfulfilled promises made in the Coalition Agreement. ${ }^{1}$ To some degree, the Opposition can also point to several Working or Expert Groups that have yet to provide actual policy changes. These Working Groups have presented reports on major employment relations platform policies such as Fair Pay Agreements, the 'Hobbit' legislation and protection of contractors, as well as social welfare changes. However, there has also been a wave of new employment relations policies as detailed in Table 1 below. These changes have prompted their fair share of political debate with the ER Amendment Act (ERAA) 2018, the vocational education and training (VET) reform, higher statutory minimum wages, and the restriction of probationary periods to small businesses being some of the political focal points.

\section{Table 1: Employment relations policy changes 2017-2020}

\begin{tabular}{|l|l|}
\hline Sept. 2017 & General Election \\
\hline Oct. 2017 & NZ First \& Labour will be in government, development of Coalition Agreement \\
\hline Dec. 2017 & Paid Parental Leave Bill passed $3^{\text {rd }}$ reading \\
\hline Jan. 2017 & Pike River Recovery Agency established \\
\hline Jan. 2017 & ER Amendment Bill \\
\hline April 2018 & Statutory Minimum Wage rise (from \$15.15 to \$16.50) \\
\hline May 2018 & Welfare Working Group (Welfare Expert Advisory Group) announced \\
\hline May 2018 & Tripartite Tasks Force to review the Holidays Act \\
\hline July 2018 & New Paid Parental Leave come into effect (up from 18 to 22 weeks) \\
\hline Dec. 2018 & ER Amendment Act passed (some changes come into force from May 2019) \\
\hline Dec. 2018 & Report from the Working Group on Fair Pay Agreements \\
\hline Feb. 2019 & Discussion document about vocational education \& training (VET) reform \\
\hline Feb. 2019 & Report of Tax Working Group released \\
\hline April 2019 & Statutory Minimum Wage rise (from \$16.50 to \$17.70) \\
\hline April 2019 & Domestic Violence Leave introduced \\
\hline May 2019 & Report of Welfare Expert Advisory Group released \\
\hline May 2019 & 90-day probationary periods restricted to organisations with less than 20 people \\
\hline May 2019 & 30-day rule re-introduced for new employees in workplaces with collective employment \\
\hline agreements \\
\hline June 2019 & Report from Working Group on changes to the 'Hobbit' legislation \\
\hline Oct. 2019 & Ministry of Business, Innovation and Employment (MBIE) releases Discussion Paper on \\
\hline Fov. 2019 & Mair Pay Agreements \\
\hline April 2020 & Statutory Minimum Wage rise (from \$17.70 to \$18.90) \\
\hline April 2020 & Education (Vocational Education and Training Reform) Amendment Act \\
\hline April 2020 & Screen Industry Workers Bill before Parliament \\
\hline June 2020 & Employment Relations (Triangular Employment) Amendment Act \\
\hline July 2020 & Paid Parental Leave raised to 26 weeks (from 22 weeks) \\
\hline July 2020 & Equal Pay Amendment Act \\
\hline
\end{tabular}

\footnotetext{
${ }^{1}$ However, when Young (2020) monitored the progress on the coalition agreement, she found that "New Zealand First has achieved or partially achieved about 80 percent of the commitments in the agreement that sealed the deal on the Coalition".
} 
In the Coalition Government's term, there has clearly been a considerable strengthening of employee rights, including increased paid parental leave, a strong rise in statutory minimum wage, equal pay legislation, and better protection of vulnerable workers. The ER Amendment Act 2018 introduced a number of employment law changes aimed to improve fairness in the workplace and deliver decent work conditions and fair wages. The Act restored previous protections for workers, especially vulnerable workers, and strengthened the role of collective bargaining in the workplace. Legislation on triangular employment relationships came into force in 2020. This legislation allows for employees to draw in third parties in their personal grievance cases if these parties are found to exercise "...or is entitled to exercise, control or direction over the employee that is similar or substantially similar to the control or direction that an employer exercise" (Employment Relations (Triangular Employment) Amendment 2019). The strengthening of employee rights has also been supported by an emphasis on enforcement through the Labour Inspectorate and WorkSafe (see below).

A real surprise has been the unexpected continuation of high levels of net migration, despite Labour's and NZ First's 2017 election campaign on reducing migration numbers (Skilling \& Molineaux, 2017). This was to mitigate skills shortages and labour market bottlenecks as unemployment fell to around four to five per cent. It was not until Covid-19 abruptly closed the borders to migrants that there was a major reset. Nonetheless, this has had a less-than-expected impact in terms of actual labour market flows since around 40,000 'Kiwis' have returned from overseas. However, there will be significant industry and regional effects as migrants are no longer available in tourism, hospitality, agriculture, and horticulture. Interestingly, the Provincial Growth Fund was a major policy initiative in 2017-2020 but it is unclear whether it has actually had significant regional labour market effects (Rutherford, 2020; Wood, 2019). The Fund has allocated most of the $\$ 3$ billion set aside for regional investments but it will probably be short-lived as both Labour and National have recorded their opposition to a continuation of the Fund.

As mentioned, the Coalition Government promised stronger 'policing' of employment standards and that has happened to some degree. There has been an increase in the number of labour inspectorate staff: in 2017, there were 60, and the Coalition Government is close to fulfilling its target of adding another 50 by 2020 (Donovan, 2017). Despite a more active labour market presence, there has still been some disquiet that these agencies continue to lack sufficient resources to be truly proactive and effective (Lees-Galloway, 2018; Lock 2020). There does appear to be a greater willingness to prosecute exploitative employers as well as 'name and shame' through the NonCompliant Employer List (Employment New Zealand, 2020). In the area of migrant exploitation, the Employment Institutions have handed down tougher decisions with large fines and even jail terms to some offending employers to set an example (Smith, 2019; Stringer, 2020). The tougher decisions have also been associated with a stronger focus on 'access to justice' and conflict resolution which has involved a rethinking of how to overcome barriers for effective resolution (Arthur, 2018; Inglis, 2019).

Overall, it is probably too early to provide a firm evaluation of the Coalition Government's employment relations changes. While there has been considerable public policy activity, there are really three problems: the full effect of new regulations has yet to be established, there are several pieces of legislation or legislative suggestions still in train, and, above all, the longer-term Covid-19 disruptions are still to be fully acknowledged in economic, social, and employment policy changes. For example, the Equal Pay Amendment Act that has just been passed, in July 2020, could unleash considerable adjustments in wage setting processes and outcomes. Likewise, the VET reforms have yet to be fully finalised and there will be unprecedented demand for upskilling and reskilling following this year's labour market dislocations. With Fair Pay Agreements, social welfare reform and protection of contractors, amongst others, still being on the political agenda, there could be another wave of regulatory change if Labour is returned to office. 


\section{In the shadow of the Covid-19 pandemic: the 2020 General Election campaign}

The impact of Covid-19 on public policy and the 2020 General Election has been pervasive and can probably only be fully understood sometime in the future. This has been a swift, and radically different economic, social and labour market situation from that experienced by most politicians, policy advisors and commentators. On Friday $28^{\text {th }}$ February, New Zealand had its first confirmed case of Covid-19. In less than a month, travel restrictions and mandatory quarantining were instituted, and where, for the first time in history, the government closed the country's borders to all but New Zealand citizens and permanent residents. While the immediate victim of border closure was the tourism sector, the impact was widespread, including firms in sectors such as retail, hospitality, accommodation, transport services, agriculture, horticulture, and the education sectors.

This was clearly a major blow to the economy but many, including the Coalition Government, were hoping that this would be relatively short-term and involve an economic rebound. Still, the government response in terms of its initial stimulus package, announced in mid-March was unprecedented, with $\$ 8.7$ billion in support of jobs and businesses and another $\$ 2.8$ billion for income support and consumer spending. The core elements of the economic package were a wage subsidy scheme where businesses with a revenue decline of 30 per cent or more could receive an immediate 12-week subsidy at 80 per cent of an employee's normal wages. These interventions were continued in the May 2020 Budget, with wage subsidies, income relief payments and leave support schemes. The eight-week extension of the wage subsidy schemes would apply to businesses with at least a 40 per cent drop in revenue.

The fast-moving trajectory of lockdown procedures saw the majority of the country's workforce swapping their traditional jobs for staying at home. However, those deemed 'essential workers', such as supermarket, healthcare, and transport workers, were required to continue working, often in environments where cases of community transmission had been clearly identified. While these workers were lauded by politicians and media alike for working during this time, health and safety concerns, combined with customer aggression, contributed to extremely stressful work environments.

As the Covid-19 situation worsened, the wage subsidy applied to all businesses, and at one point, it was supporting a majority of New Zealand workers - 70 per cent of all jobs, with 1.7 million jobs protected by the scheme at a cost of $\$ 14$ billion. Its effectiveness was demonstrated when the unemployment rate declined to four per cent; clearly a statistical outlier as sectoral employment dislocation was taking hold across the economy (Nippert \& Ng, 2020). The wage subsidy scheme was broadly supported across the political spectrum despite some questions from the Opposition whether payments should have been directed at businesses rather than workers. National was also less supportive of higher minimum wages and benefits while Labour advocated these changes as both socially just and as a growth-generating policy. Overall, both the major parties found themselves in unknown territory as the reactions to the disruptions of Covid-19 - in order to avoid massive unemployment problems - shifted the goal posts on economic, social and employment relations policies.

With the general public being bombarded by major economic, social and employment interventions, and vast sums of public funding being spent (Mitchell \& Rodriques, 2020), it is understandable if voters were slightly overwhelmed going into the election campaign. This was probably not helped by Covid-19 also influencing the postponement of the election date. On $17^{\text {th }}$ August, Prime Minister Ardern announced, under considerable pressure from other political parties, that the election would be postponed by a month, from $19^{\text {th }}$ September to $17^{\text {th }}$ October. This probably threw a lifeline to some struggling political parties who had been overshadowed with the focus on Covid-19 responses.

With a delayed election campaign start and Auckland in lockdown level 3, there appeared, initially, to be little difference in the public policies of National and Labour, as both parties were dwarfed by the 
health and economic reactions to the Covid-19 pandemic. With Labour, under the meteoric rise of Prime Minister, Jacinda Ardern, scoring well enough in the public polls to govern on its own, National was urged by its supporters to present an alternative strategy (Hooton, 2020). Since then, National has presented a very different economic, social and, to some degree, employment relations position. As can be seen from Table 2 below and the subsequent discussion, the voter is presented with major public policy differences; probably more differences than have been the case in several of the last elections.

On $17^{\text {th }}$ September, it was officially announced that the New Zealand economy was in a recession with a massive 12 per cent contraction of GDP recorded in the June quarter. This allowed Judith Collins to make the assertion that National would be better to manage the economy: "There was a better way and the government should have taken it" (in Wilson, 2020). This was followed by an announcement of temporary, 16-months tax cuts, mainly through changes to tax brackets, and improved business depreciation. It clearly placed the National Party policy position as markedly different from Labour, who had announced a rise in the top tax income bracket of 39 per cent for high income earners above $\$ 180,000$ (Huffadine, 2020). While these tax cuts and the use of $\$ 4.9$ billion of borrowed money from the Covid-19 reserve fund was labelled by Finance Minister, Grant Robertson, as "desperate and reckless" (in Malpass, 2020), they highlighted a difference on taxation as well as they signalled major future differences in terms of public sector, health, education and welfare expenditures.

Moreover, with only three weeks to Election Day, there now appears to be many major differences between the two parties' employment relations positions, despite both having yet to present a comprehensive employment policy platform. Labour is in a more advantageous position as it can point to changes under the Coalition Government (see Table 1) as well as many attempts to drive further changes. Furthermore, the Labour Party has also a much stronger, well-published position on employee protection, being able to highlight increases in statutory minimum wages, support of living wages in the public sector and a rise in sick leave entitlements (see the next section; Wade 2020). The Labour Party has a number of different suggestions on how to enhance collective bargaining, especially a move towards Fair Pay Agreements while the National Party is silent in this policy area.

The National Party has not presented an employment relations policy platform, and only limited information is available on National's website (see national.org.nz). Important promises are increased funding for business, including $\$ 10,000$ incentives to hire staff, and funding a creation of 50,000 jobs. The Party has also announced that it will reverse recent employment relations changes by the Coalition Government (especially changes derived from the ER Amendment Act 2018), re-institute the options of 90-day probationary periods for all businesses and a more moderate rise in statutory minima. The well-worn phrases of 'cutting red tape' and 'looking better after business interests' could encompass significant changes to employment relations. Thus, there are important differences between the two parties, but it is also fair to say that these differences have yet to figure much in the debates of this election campaign. 
New Zealand Journal of Employment Relations, 45(1): 3-13

Table 2. Employment relations policy positions, September 2020

\begin{tabular}{|c|c|c|}
\hline Policies & National Party & Labour Party \\
\hline $\begin{array}{l}\text { Collective } \\
\text { bargaining }\end{array}$ & $\begin{array}{l}\text { Collective bargaining is not discussed on } \\
\text { their website. }\end{array}$ & $\begin{array}{l}\text { Commitment to introduce Fair Pay Agreements if elected } \\
\text { Improving bargaining rights for all workers and contracting } \\
\text { arrangements. }\end{array}$ \\
\hline $\begin{array}{l}90 \text { Day-Tria } \\
\text { Periods }\end{array}$ & $\begin{array}{l}\text { Reinstate the 90-day trial period for all } \\
\text { businesses. }\end{array}$ & $\begin{array}{l}\text { Retain trial periods for SMEs but remove the fire-at-will } \\
\text { provision with referee system that is fair and simple. }\end{array}$ \\
\hline $\begin{array}{l}\text { COVID-19 } \\
\text { workplace } \\
\text { support }\end{array}$ & $\begin{array}{l}\text { National backs the private sector to } \\
\text { create jobs through the job start scheme: } \\
\text { - Providing a } \$ 10,000 \text { cash } \\
\text { payment to businesses that hire } \\
\text { additional staff. } \\
\text { - Incentivising' up to } 50,000 \text { new } \\
\text { jobs (mechanisms have not been } \\
\text { announced). }\end{array}$ & $\begin{array}{l}\text { Wage Subsidy Scheme. } \\
\text { Covid-19 income relief payment, supporting New Zealanders } \\
\text { who lose their jobs due to the impact of Covid-19, as they find } \\
\text { new employment or retrain. } \\
\text { Support package to assist businesses in hiring at least } 40,000 \\
\text { New Zealanders whose employment is impacted by Covid-19. } \\
\text { Free trades training for two years in 'critical industries'. } \\
\text { Investment in conservation jobs. }\end{array}$ \\
\hline $\begin{array}{l}\text { Enforcemen } \\
\text { of } \\
\text { legislation }\end{array}$ & tIncreased powers for Labour Inspectors & $\begin{array}{l}\text { Funding set out in the 2019-20 Budget for increasing the number } \\
\text { of labour inspectors. } \\
\text { Employment Policy Advice: funding to increase MBIE capacity } \\
\text { to deliver skills and employment advice on employment } \\
\text { standards. }\end{array}$ \\
\hline $\begin{array}{l}\text { Statutory } \\
\text { Minimum } \\
\text { Wage }\end{array}$ & $\begin{array}{l}\text { Continue 'responsible' rises in statutory } \\
\text { minimum wage, defer the } 2021 \text { statutory } \\
\text { minimum wage increase if elected. }\end{array}$ & $\begin{array}{l}\text { Work toward a minimum wage of two-thirds of average wage, an } \\
\text { increase to } \$ 20 \text { an hour by } 2021 \text {. }\end{array}$ \\
\hline Equity & $\begin{array}{l}\text { There appears to be no equity measures } \\
\text { discussed on National's website. }\end{array}$ & $\begin{array}{l}\text { There are pay equity claims near completion and progressing for } \\
\text { teacher aides, early child education workers, education } \\
\text { administration workers, DHB administrative staff, DHB nurses, } \\
\text { DHB midwives, DHB allied health staff, local government } \\
\text { library assistants, social workers, workers in the social service } \\
\text { sector and public service admin/clerical workers. } \\
\text { Funding of ongoing work toward implementing pay parity for } \\
\text { early childhood teachers. }\end{array}$ \\
\hline $\begin{array}{l}\text { Living } \\
\text { Wage }\end{array}$ & $\begin{array}{l}\text { The Living Wage is not discussed on } \\
\text { National's website. }\end{array}$ & $\begin{array}{l}\text { Extension of Living Wage guarantees to contractors to the public } \\
\text { sector. }\end{array}$ \\
\hline Dismissal & $\begin{array}{l}\text { Repeal the Coalition Government's } \\
\text { changes. }\end{array}$ & Re-instatement as primary remedy \\
\hline $\begin{array}{l}\text { Best } \\
\text { practice }\end{array}$ & $\begin{array}{l}\text { Repeal the Government's changes to the } \\
\text { ERA and overturn mandatory rest and } \\
\text { meal breaks } \\
\text { Simplify the employment dispute } \\
\text { resolution process. } \\
\text { Get rid of the 'no-win, no-fee' provisions } \\
\text { in the ERA. }\end{array}$ & $\begin{array}{l}\text { Implement HPES by encouraging employer/union participation } \\
\text { and engagement. } \\
\text { Expand and enhance skill and industry training. }\end{array}$ \\
\hline
\end{tabular}

Sources: Labour Party and National Party web sites. 


\section{The BIG policy issues in this election campaign}

This is an election where the unusual context of the Covid-19 pandemic and its unfolding associated economic and social approaches have dominated the political debate. As a result, both of the major parties have recorded significant shifts in their economic approach in a very short time period. The dominant conservative fiscal approach with low debt levels has been forsaken for a debtfunded rescue mission in respect of economic growth, employment, and social fallouts. The National Party has followed the lead of the Coalition Government by announcing massive investments in infrastructure, where the main difference appears to be that National is favouring road building while Labour is favouring public transport solutions. Although the focus is on 'shovel ready' projects, both parties could have been more precise and comprehensive in their overall approach instead of using regional announcements of various projects. While these infrastructure projects are bound to generate employment, it is unclear just how much employment will be generated and how effective the employment creation will be.

As business closures, restructuring, and unemployment threats in several industries come to the fore, there will be further pressures on constraining debt levels, and how to accommodate these pressures will highlight party differences. The National Party has already indicated that it will pursue a return to balanced budgets (similar to its approach in 2010-2017) and the use of short-term, temporary tax cuts to stimulate the economy. Although Labour appears to have a longer timeframe in bringing down debt levels; another major difference could be its Just Transition approach (already used in respect of a moratorium on gas and oil exploration) and the nascent industry policy directions discussed in the Future of Work Forum. Associated with these differences, there will be, as discussed below, employment relations differences in respect of employee protection, collective bargaining, and vocational education and training.

It is concerning, however, that neither party appears to have a clear, coordinated plan to overcome the pre-Covid-19 circumstances of a low pay and low productivity economy that was essentially reliant on migrant labour (Cormack, 2020; Edwards, 2020). This charge has been partly acknowledged by the Finance Minister, Grant Robertson: "this is not the time to be making grand promises when there is so much uncertainty in the world." (in Newstalk, 2020). Several economists have stressed that, in the past, New Zealand has missed chances to deal with some of its embedded economic, social and employment issues (Dann, 2020; MacCulloch, 2020). It appears that the potential outcome of this election could be another missed opportunity.

A key issue will be employee protection, where Labour, as part of the Coalition Government, has already established a distinct position by: implementing large increases in the statutory minimum wage and benefits, supporting the living wage in public sector organisations, introducing significant rises in recent public sector agreements, expanding sick leave entitlements, and attempting to deal with pay equity. This clearly cuts across National's position which continues its focus on tax cuts, business costs, and a tight rein on public expenditure. The promises of the National Party to revert to the situation where all organisations have the right to negotiate probationary periods for new employees (the so-called 90-day rule) and roll back some of the Coalition Government's recent changes present clear dividing lines between the two major parties. Furthermore, the debate surrounding contracting (including dealing with the 'Hobbit' anomaly) could also lead to significant changes, and while National has yet to announce any policy position, it is unlikely that it will support the regulation of contractors and subcontracting firms.

Since the 2000 enactment of the ERA, there have been various attempts by Labour-led governments to support the ERA's object of enhancing collective bargaining. The current Coalition Government has been less pro-active in that respect, with the ER Amendment Act 2018 mainly, re-introducing supports that had limited effect in the past, and with the Fair Pay Agreements languishing after MBIE's 
consultation process in late 2019. However, Prime Minister Ardern has made Fair Pay Agreements a clear election promise, and there is obvious union pressure to make this happen. The National Party has condemned Fair Pair Agreements but has largely ignored collective bargaining and appears satisfied with the status quo. National's limited attention to collective bargaining is problematic since Labour appears ready to push several collective bargaining initiatives, especially in the public sector. However, National hints at further changes to conflict resolution in the Employment Institutions and the suggestion of overturning the 'no-win, no-fee' approach could be interesting, even for the Labour Party.

There is no doubt that the massive labour market disruption caused by Covid-19 will demand an exceptional upskilling and reskilling support for those who lose their jobs. While both parties have both acknowledged the necessity of overcoming employment dislocation, there appears to different approaches to vocational education and training (VET). Labour has already started a large reform of VET structures and is obviously continuing that effort, with additional funding of nearly $\$ 2$ billion of apprenticeships and VET interventions (Collins, 2020). Although National is not supportive of Labour's VET reform, it has promised significant funding for a JobStart scheme to bolster employer incentives to take on apprentices and new employees. Finally, the drop in international students after the border closure has had significant negative financial impacts on universities and polytechnics, but neither parties have announced any measures so far (although Labour has stopped further expansion of its fees-free policy). National has urged consideration of an early, safe opening of borders for international students but it is unclear what the criteria are for such an opening.

\section{Conclusion}

This is an election where Labour's and National's policy positions have been shaped by the Covid-19 pandemic. In National's case, it has prompted leadership battles, party turmoil, and sharply declining voters' support. These changes have certainly influenced the abrupt policy adjustments during the election campaign. While Labour appears to continue the policy platform of the Coalition Government, this government has had to introduce major policy interventions which have cut across traditional financial positions to mitigate large-scale labour market disruptions. Both parties have been willing to support large-scale interventions and they have both announced major government involvement in infrastructure, training, and employment packages. These changes and promises will influence the economic and labour market context of employment relations in years to come.

While it is disconcerting that neither of the major parties appear to have a clear, coherent plan for employment relations developments over the medium to longer term, it is obvious that employment relations and its economic and social context have moved considerably since 2017. The Covid-19 generated dislocations will generate further employment relations changes, but the actual form of these changes depend on economic pressures and which party will form the next government. There are obviously reactive interventions occurring and, regardless of who forms the next government, further interventions will be under consideration and necessary in the coming months. With that background, it may be churlish to ask: how will the two main parties set the economy and employment relations on a road towards sustainable, high wage and highly productive employment relationships? 


\section{References}

Arthur, R. (2018). Barriers to participation. LawTalk, 923: 75-76.

Collins, S. (2020, May 15). Trade package 'incredible'. New Zealand Herald, A7.

Colmar Brunton (2020). 1 NEWS Colmar Brunton Poll 8 - 12 February 2020. https://static.colmarbrunton.co.nz/wp-content/uploads/2019/05/8-12-Feb-2020_1-NEWSColmar-Brunton-Poll-report-.pdf

Cormack, D. (2020, September 17). Doing nothing seems to be the strategy in this election. New Zealand Herald, A3.

Dann, L. (2020, May 3). Is it time for another economic revolution? New Zealand Herald, 44-45.

Donovan. E. (2017, November 6). Labour inspector number set to double in 3 years. RNZ (Radio NZ). https://www.rnz.co.nz/news/national/343168/labour-inspector-numbers-set-to-doublein-3-years

Edwards, B. (2020, August 6). Political Roundup - Where is the contest of ideas in the election campaign? New Zealand Herald. https://www.nzherald.co.nz/nz/news/article.cfm?c id=1\&objectid=12354423

Employment NZ. (2020). Published Stand Down List 23 September 2020. https://www.employment.govt.nz/assets/Uploads/employers-visa-stand-downreport.pdf

Foster, B. \& Rasmussen, E. (2017). The major parties: National's and Labour's employment relations policies. New Zealand Journal of Employment Relations, 42(2), 95-109.

Hooton, M. (2020, September 18). National takes its last throw of the dice. New Zealand Herald, https://www.nzherald.co.nz/business/news/article.cfm?c_id=3\&objectid=12365868

Huffadine, L. (2020, September 21). RNZ guide to party policy for general election 2020. RNZ (Radio NZ). https://www.rnz.co.nz/news/political/426340/rnz-guide-to-party-policy-forgeneral-election-2020

Inglis (Chief Judge), C. (2019). Barriers to participation in Employment Institutions. New Zealand Law Society. https://www.lawsociety.org.nz/news/lawtalk/issue-933/barriers-to-participationin-the-employment-institutions $2 /$

Lees-Galloway, I. (2018). Protecting our workers from exploitation. https://www.beehive.govt.nz/release/protecting-our-workers-exploitation

Lock, H. (2020, July 28). Concerns efforts to stop migrant exploitation don't go far enough. RNZ (Radio NZ). https://www.rnz.co.nz/news/national/422168/concerns-efforts-to-stop-migrantexploitation-don-t-go-far-enough

MacCulloch, R. (2020, September 16). Do not let this Covid crisis go to waste. New Zealand Herald, A25. 
New Zealand Journal of Employment Relations, 45(1): 3-13

Malpass, L. (2020, September 19 ). Election 2020: National tax cuts finally brings some decent meat to the BBQ. Stuff. https://www.stuff.co.nz/national/politics/opinion/122820033/election2020-national-tax-cuts-finally-brings-some-decent-meat-to-the-bbq

Mitchell, C. \& Rodriques, F. (2020, 30 August). How to spend \$36b in just five months. Sunday Star-Times, 8-9.

O'Brien, T. (2020, 18 May). National and Labour neck-and-neck in new Newshub-Reid research Poll. Newshub. https://www.newshub.co.nz/home/politics/2020/05/newshub-reid-research-polljacinda-ardern-goes-stratospheric-simon-bridges-is-annihilated.html

New Zealand Labour Party \& New Zealand First (2017). Coalition Agreement: New Zealand Labour Party \& New Zealand

First. https://img.scoop.co.nz/media/pdfs/1710/362429780LabourandNewZealandFirstCoaliti onAgreement.pdf

Newstalk ZB. (2020, August 4). Robertson: Now is not the time to be making grand promises on policy. https://www.newstalkzb.co.nz/on-air/heather-du-plessis-allan-drive/audio/grantrobertson-now-is-not-the-time-to-be-making-grand-promises/

Nippert, M. \& Ng, K. (2020, August 8). Job loss predictions - how did we get them so wrong? New Zealand Herald, C1-C3.

Rasmussen, E. \& Anderson, D. (2010). Between unfinished business and an uncertain future. In E. Rasmussen (Ed.), Employment Relationships. Workers, Unions and Employers in New Zealand (pp. 208-223). Auckland University Press.

Rutherford, H. (2020, August 4). Auditor-General says public deserves a proper assessment of PGF 'as quickly as possible'. New Zealand Herald.

https://www.nzherald.co.nz/business/news/article.cfm?c_id=3\&objectid=12353700

Skilling, P. \& Molineaux, J. (2017). New Zealand's minor parties and ER policy after 2017. New Zealand Journal of Employment Relations, 42(2), 110-128.

Smith, A. (2019, May 19). Auckland sweet shop owners who paid migrant workers $\$ 6 / \mathrm{hr}$ jailed for exploitation. RNZ (Radio NZ) https://www.rnz.co.nz/news/national/388917/auckland-sweetshop-owners-who-paid-migrant-workers-6-hr-jailed-for-exploitation

Stringer, C. (2020). What slavery case exposed about exploitation in NZ. Ideasroom. https://www.newsroom.co.nz/ideasroom/what-slavery-case-exposed-about-exploitation-in-nz

Wade, A. (2020, September 20). Labour vows sick leave boost. New Zealand Herald, 2

Wilson, P. (2020, September 18). Week in Politics: Recession fires up the campaign. RNZ (Radio NZ). https://www.rnz.co.nz/news/political/426401/week-in-politics-recession-fires-up-thecampaign

Wood, J. (2019). A Risk Worth Taking: Ensuring The Provincial Growth Fund Is Fit For Purpose (Policy Paper). Maxim Institute. https://www.maxim.org.nz/wpcontent/uploads/2019/02/WEB-A-Risk-Worth-Taking-Provincial-Growth-Fund.pdf

Young, A. (2020, July 18). Marking the NZ First deal. New Zealand Herald, A18. 